Трофимова И.Н.

\title{
ГРАЖДАНСКИЙ АКТИВИЗМ В РОССИИ: НОВЫЕ РЕАЛИИ
}

Аннотация: Статья посвящена изучению проблемы гражданского активизма в контексте происходящих в российском обществе соичально-политических изменений. Гражданский активизм рассматривается как сложное социальное явление, включающее различные поведенческие практики, ценности, формы и мотивы участия граждан и их групп в общественно-политической жизни. Особое внимание уделено изучению динамики гражданского активизма, обусловленной происходящчими в стране и мире социокультурными, социиальными и политическими изменениями. В качестве ее основной причинь рассматривается рост гражданской субъектности общества и появление новых субъектов гражданского действия. Анализ проблемы учитывает основные положения теории социальных изменений и теории гражданской активности, позволяющих определить новизну и специифику функционирования сферы гражданского активизма в российском обществе. Сделан вывод, что гражданский активизм является органичной частью жизни современного общества и представляет собой не реакцию на дисфункции и противоречия социально-политической системы, а признак и условие ее нормального функционирования и развития. Происходящие изменения получают рациональное осмысление и общественную оценку в коллективных действиях граждан, что способствует определению наиболее перспективных изелей развития общества.

Review: The article is devoted to the problems of civil activism in terms of the socio-political transformations going on in the Russian society now. Civil activism is viewed as a complex social phenomenon that includes different behavior, values, forms and motives of participation of citizens and their groups in social and political life. Special attention is paid to the development of civil activism as a result of socio-cultural, social and political changes happening in the country and all over the world. The author views the growth of civil subjectivity of the society and appearance of new actors of civil actions as the main trigger. Analysis of the problem includes the analysis of the main provisions of the theory of social changes and the theory of civil activity allowing to define the novelty and specifics of the sphere of civil activism in the Russian society. It is concluded that civil activism is a natural part of life of a modern society. It is not a response to dysfunctions or contradictions of the socio-political system but a sign and condition of its normal functioning and development. Social and political transformations receive a rational interpretation and social evaluation through collective actions of citizens which contributes to the determination of longterm targets of the social development.

Ключевые слова: Гражданский активизм, гражданское участие, демократия, социальное доверие, институциональное доверие, социильно-политическое развитие, Россия, социалное участие, общественное участие, политическое участие.

Keywords: Civil activism, civil participation, democracy, social trust, institutional trust, socio-political development, Russia, social participation, political participation.

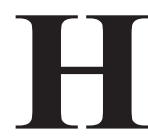

едемократический контекст неполитического активизма ${ }^{1}$. Проблема гражданского участия занимает важное место в истории и теории демократии. Вопрос заключает-

\footnotetext{
${ }^{1}$ Исследование проведено в рамках проекта «Гражданский активизм и самоорганизующиеся практики: новые реалии» при финансовой поддержке РГНФ (грант № 14-03-00707).
}

ся в определении, является ли демократия особым типом народной власти, при которой граждане вовлечены в самоуправление и самоорганизацию, или средством легитимации решений тех, кто находится у власти. Различные модели демократии - классические и современные - по-разному обосновывают роль, компетенции и пределы гражданского участия в демократическом процессе, но ни одна из них 
не может в полной мере охватить то многообразие форм гражданской активности, которые мы наблюдаем сегодня во всем мире. Тем не менее, сам факт роста гражданской активности свидетельствует о том, что демократия по-прежнему остается единственным нарративом, способным легитимно сформулировать ценности, обозначить их границы и взаимосвязи, предложить способы разрешения ценностных конфликтов. Именно в рамках демократического процесса формируется программа изменений, в которой и посредством которой насущные и наиболее значимые вопросы получают лучшую возможность для обдумывания, обсуждения и решения, чем при каком-либо другом режиме 2 .

Между тем, многие исследователи отмечают тенденцию сужения представительства интересов широких социальных групп в публичной политике (Р. Дзолло, Дж. Кин, К. Крауч, А. Турен и др.). Одной из ее причин является высокая скорость происходящих социальных изменений, ведущая к растущей неопределенности в понимании основных ценностей, плюрализму и диффузии социальных пространств и идентичностей, снижению управляемости, росту рисков в процессе принятия социально значимых решений. Политические институты, призванные выступать посредниками и выразителями интересов различных социальных групп, постепенно утрачивают связь с обществом, превращаясь в инструменты обслуживания частных и корпоративных интересов. Растущее недоверие политическим институтам со стороны граждан усиливает взаимное отчуждение власти и общества, создает предпосылки для активизации социального взаимодействия на низовом уровне, вне формальных институциональных рамок. Особое значение данные тенденции имеют для нашей страны, где демократическое представительство на протяжении всей ее истории по большей части носило формальный характер, и происходящие сегодня социально-политические изменения с особой остротой поставили вопрос о перспективах демократического развития российского общества.

Степень воплощения демократических идеалов в деятельности демократических институтов зависит как от конкретно-исторических условий их становления и развития, так и от особенностей теку-

${ }^{2}$ Хелд Д. Модели демократии. М.: Издательский дом «Дело» РАНХиГС, 2014. С.429. щего социально-политического контекста. Именно контекст в его глобальном, национальном, региональном и ситуативном измерениях определяет многообразие форм и динамику гражданской активности ${ }^{3}$. Современный демократический процесс представлен множеством моделей, отличающихся содержанием и эффективностью участия в нем различных социальных и политических акторов. Следовательно, формы коллективной самоорганизации в разных условиях и контекстах будут иметь специфический характер. В последние три-четыре года в российском общественно-политическом дискурсе появилась тенденция вычленения из всей совокупности общественной жизни феномена «неполитического» гражданского активизма. При этом исследователи акцентируют внимание не только на особенностях текущего политического цикла, но также целом ряде социокультурных, экономических, политических, структурных и технологических изменений, в своей совокупности приведших к появлению новых субъектов и моделей социального взаимодействия 4 .

В начале 2010-х гг. в российское публичное пространство пришли новые самоорганизованные группы граждан, ориентированные на рациональные модели социального действия и индивидуальный ценностный выбор, выходящие за рамки представлений о традиционных для России патерналистских отношениях между властью и обществом. «Креативный класс», «сетевые хомячки», «бандерлоги», «рассерженные горожане», «новая интеллигенция» - термины, которых не было до недавнего времени. Сегодня они обозначают новых субъектов гражданского действия, объединенных не по идейно-политическим или социально-экономическим статусным признакам, а по причине общей социокультурной идентичности и необходимости решения общих проблем, что, однако, не исключает, а скорее даже обостряет возникающие социальные конфликты, поскольку речь идет о свободном выборе, а не подчинении «рекомендованным сверху» ценност-

\footnotetext{
3 Яницкий О.Н. Социальные движения: теория, практика, перспектива. М.: Новый хронограф, 2013. С.325.

${ }^{4}$ См.: Петухов В.В. Гражданская активность как альтернатива антидемократическому тренду российской политики // Полис. 2013. № 5. С.87-99; Российский неполитический активизм. Отчет о результатах исследования. Пермь: ПК «Астер», 2014.
} 


\section{Политика и общество 9 (117) 2014}

ным ориентирам. Социальное движение в современных условиях становится одновременно культурно ориентированным и социально конфликтным действием определенных социальных групп, которое обусловлено не диспозициями господства или неравенства, а претензиями на общественную значимость тех культурных моделей, знаний и моральных норм, носителем которых они являются.

В то же время рост гражданской активности во многом является результатом развития ситуации начала 2000-х гг. С одной стороны, политическую апатию и абсентизм этих лет можно рассматривать как тихий протест и оппозиционность, готовые «прорваться» в определенный момент 5 . С другой, в это время складывался потенциал новых движений, в основе которых лежали происходящие технологические, экономические и социальные изменения. Эффект социально-экономического роста и развития проявился в существенном изменении общественных настроений. Угрозы экономического коллапса, территориальной дезинтеграции и гражданской войны ушли на периферию общественного сознания, но вместе с этим вырос запрос на современные политические институты, преодоление застоя в политической сфере 6 . Рост социально-политической субъектности способствовал своеобразной эмансипации гражданского общества в том, что касается возможности участия в публичной политике, в деятельности политических и общественных институтов, процессе принятия социально значимых решений.

В результате всех изменений к началу 2010-х гг. оформились две взаимосвязанные тенденции: рост запроса на современные политические институты и рост потребности в социальном взаимодействии, по крайней мере, в рамках тех неформальных самоорганизующихся коллективов, чьи интересы были связаны с решением конкретных социальных проблем. Обе эти тенденции были озвучены в программной статье Президента Д. Медведева «Россия, вперед!» в сентябре 2009 г.: «Демократические институты в целом сформированы и стабилизированы, но их качество весьма далеко от идеала. Гражданское общество слабо, уровень самоорганизации и

\footnotetext{
${ }^{5}$ Психология политического восприятия в современной России / под ред. Е.Б. Шестопал. М.: РОССПЭН, 2012. С.378.

${ }^{6}$ Россия на новом переломе: страхи и тревоги / под ред. М.К. Горшкова, Р. Крумма, В.В. Петухова. М.: Альфа-М, 2009. C.150-151.
}

самоуправления невысоки7». Целью политической модернизации объявлялось становление предельно открытой, гибкой и внутренне сложной политической системы, адекватной динамичной, подвижной, прозрачной и многомерной социальной структуре, отвечающей культуре свободных, обеспеченных, критически мыслящих, уверенных в себе людей. Несмотря на некоторую «лубочность» планов и тот факт, что идея политической модернизации исходила «сверху», тем не менее, было очевидно стремление власти учитывать происходящие в стране перемены. Единственным, чего власть не пожелала учесть, стали растущая автономия, альтернативность и оппозиционность новых форм гражданской самоорганизации. Наметившийся анти-демократический тренд и последовавшие в 2011-2012 гг. протестные выступления свидетельствовали об обострении проблемы взаимодействия власти и общества в виде столкновения интересов правящей элиты и новых субъектов гражданского действия. Протестные коллективные действия служат основой социальных движений не потому, что эти движения всегда насильственны и экстремальны, но потому что это - главный и часто единственный ресурс, который есть у обычных людей для демонстрации своих намерений против хорошо организованных оппонентов и всесильного государства ${ }^{8}$.

Гражданский активизм: комплексная парадигма исследования. Гражданский активизм сложное социальное явление, и его изучение включает широкий спектр различных подходов, трактовок, систематизаций в выявлении его сущностных оснований и взаимосвязей с другими социальными явлениями. Отсюда многообразие концептуальных схем: политическое - гражданское, конфликт - диалог, глобальное - локальное, коллективное - индивидуальное, мораль - идеология и др. Концептуальное решение в рамках отдельных схем имеет свою конкретно-историческую обусловленность, а также актуальный набор проблемно-тематических и смысловых референций, разрабатываемых для более полного раскрытия природы данного феномена.

\footnotetext{
7 Россия, вперед! Статья Дмитрия Медведева. 10 сентября 2009 г. См. официальный сайт Президента РФ http://kremlin. ru/transcripts/5413 (дата просмотра 20.03.2014 г.).

${ }^{8}$ Tarrow S.G. Power in Movement: Social Movements and Contentious Politics. Cambridge: Cambridge University Press, 2011. P.7-8.
} 
Одним из важных вопросов является вопрос о «новизне» гражданского неполитического активизма в России в начале 2010-х гг. На наш взгляд, существует несколько уровней в решении данного вопроса. Во-первых, речь идет о широком контексте социальных изменений, связанных с наступлением эпохи позднего модерна и постмодерна. Трансформация социальных связей и структур в коммуникации, кризис социальных идентичностей и рост индивидуализма, усиливающееся недоверие социальным и политическим институтам - все эти изменения обусловили поиск новых, альтернативных оснований для восстановления доверия, солидарности и социальной стабильности. Расширение возможностей для неформальной самоорганизации граждан обусловило необходимость в переходе от изучения социопсихологических (поведенческих) аспектов участия в коллективных движениях к анализу движений в политическом и социокультурном контексте и как фактора институциональных изменений ${ }^{9}$ Сутью нового подхода стало понимание социальных движений не как реакции на дисфункции и противоречия социальной системы, но как условия ее нормального функционирования и развития. Социальные институты не предзаданы, не спущены сверху, но являются результатом социального творчества. «Новые движения» предполагают перекраивание социальных пространств и границ на глобальном, национальном, местном и индивидуальном уровнях в зависимости от противоречивых интерпретаций окружающей действительности индивидами ${ }^{10}$.

Другой уровень решения вопроса о «новизне» гражданского неполитического активизма в России связан с пониманием особенностей функционирования ценностно-институциональной системы. Практика, особенно отечественная, показала, что институты не могут быть формально перенесены на какую-то бы ни было почву. Социально-политическое развитие представляет собой сочетание процессов различного уровня, динамики и последовательности. Если социокультурные факторы долгосрочны и определяют инкрементный харак-

\footnotetext{
${ }^{9}$ Павлова Т.В. Социальные движения как фактор трансформации институциональной среды: проблемы теории // Полис. 2008. № 5. С.113.

${ }^{10}$ Touraine A. Social transformations of the twentieth century // International Social Science Journal. 1998. № 156. P.171.
}

тер развития, то политические факторы действуют краткосрочно и во многом обусловливают дискретность институциональных изменений. Институты, возникшие в ходе политической борьбы, отражают преобладающий баланс власти в обществе в данный момент, и в перспективе они должны измениться либо в соответствии с изменением баланса сил среди основных политических акторов, либо в соответствии с преференциями и интересами большинства населения. Политический выбор, если он привел к институционализации и формированию «зависимости от маршрута», впоследствии формирует специфическую политическую культуру, которая в дальнейшем определяет правила, нормы, стереотипы поведения. В условиях, когда политический режим вынужден опираться на противоположные ценности либерального меньшинства и консервативно настроенного, традиционалистского большинства, то перспективы его развития по-прежнему остаются зависимыми от тонкой настройки системы общественно-политических ценностей. И в данном смысле, непременное условие и источник демократического развития стоит искать не среди формальных публичных институтов, а среди неформальных гражданских инициатив и в коллективном гражданском действии.

В каждой стране складываются свои условия для проявления гражданской активности. В данном смысле гражданские движения в России являются важным механизмом функционирования всей социально-политической системы, опосредующим ее сущностные, структурные и функциональные характеристики. Поэтому изучение качественных особенностей уровня и характера общественно-политической активности на современном этапе, новых форм гражданского активизма и каналов его реализации напрямую связано с решением проблемы социальнополитической модернизации, так остро стоящей перед российским обществом. Только на уровне конкретного социального актора - группы или индивида - возможна реконструкция единства традиций и новаций, технологического и социального, субъективного и объективного, общественного и политического и других диссоциаций постсовременности ${ }^{11}$.

Политическое, гражданское, социальное: проблема структурирования интересов. Важ-

\footnotetext{
${ }^{11}$ Touraine A. What Is Democracy? Oxford: Westview Press,
} 2008. P.2. 


\section{Политика и общество 9 (117) • 2014}

ной методологической предпосылкой в поиске ответа на вопрос о сущности «нового» гражданского активизма является определение специфики функционирования общественной и политической сферы. Стоит отметить, что существуют различные интерпретации данного вопроса. Начать стоит с того, что политическая мысль долгое время рассматривала гражданское и политическое в нераздельном единстве. Дж. Локк подчеркивал, что политическое, или гражданское общество существует тогда, когда люди объединяются, отказываясь от своей власти, связанной с их естественным состоянием, и передают эту власть обществу ${ }^{12}$. Данная традиция имеет место и сегодня; более того, на наш взгляд, она получила свое развитие в виде концепции публичной политики, в рамках которой легитимность и эффективность государственных институтов напрямую зависят от гражданского участия в процессе выработки и принятия социально значимых решений. Здесь идея гражданского участия предполагает максимально возможное включение или вовлечение граждан в процесс управления общественными и государственными делами. В данной трактовке гражданское участие осуществляется в рамках существующих законов и каналов коммуникации, предварительных договоренностей с властными структурами и пр. Например, гражданское участие в местном самоуправлении является формой участия населения по месту жительства, включая территориальное общественное самоуправление, сходы, муниципальные референдумы и слушания и т.п. Здесь более четко определены участники взаимодействия, осуществляемого, как правило, между представителями гражданского общества и власти, т.е. воспроизводится партиципаторная модель демократического устройства общества.

В известной степени современный дискурс публичной политики наследует концепции Дж. Локка и распространен, прежде всего, в развитых западных демократиях. Для нашей страны он представляет собой определенную методологическую новацию как своего рода возможность преодолеть противопоставление государства и общества, которое фактически утратило свой эвристический потенциал в современных условиях. И все же доминирующим в российском общественно-политическом дискурсе

12 Локк Дж. Два трактата о правлении. М.: Социум, 2014. C.308. остается нормативное разделение, и даже противопоставление, гражданского и политического, что не в последнюю очередь связано со спецификой политической организации российского общества, политическими традициями и противоречивыми результатами демократизации «по-российски».

В широком смысле политическое участие сегодня определяется как легальная деятельность граждан, которая имеет своей целью оказание влияния на политические институты или отдельных политиков в процессе принятия управленческих или властных решений ${ }^{13}$. Примером такой деятельности являются участие в голосовании, политическое лоббирование, участие в работе политических партий. В своем содержании политическое участие - это специфические интересы, попытка изменить властные отношения внутри существующей политической системы с целью приобретения влияния на процесс принятия решений ${ }^{14}$. С позиции правящих групп, политическое участие служит укреплению приоритета их собственных интересов в рамках формально легитимного социального консенсуса. С позиции подчиненных групп - участие является способом усиления их влияния на процесс принятия решений посредством изменения институциональных властных отношений. При этом неорганизованные, или «забытые группы» (М. Олсон), не имеющие лобби и не оказывающие давления, составляют основную часть населения, обладающего жизненно важными интересами. Интересы подчиненных и слабо организованных групп, по определению, не могут быть полностью репрезентированы и включены в политическую повестку дня. Они всегда в той или иной степени исключены из политического участия и имеют шанс проявить себя только через не институциональные формы коллективных действий.

Что касается разделения гражданского, политического и социального как составляющих элементов активистского движения, то в значительной степени оно обусловлено различием в целях. По мнению ряда исследователей, специфика гражданского участия заключается в стремле-

${ }^{13}$ Verba S., Norman H., Nie J. Participation and Political Equality: A Seven-Nation Comparison. Cambridge: Cambridge University Press, 1978. P.46.

${ }^{14}$ Melucci A. Challenging Codes: Collective Action in the Information Age. Cambridge: Cambridge University Press, 1996. P.307. 
нии изменить саму схему взаимодействия между гражданами и властью, поставить органы власти под контроль граждан и тем самым добиться верховенства права и равенства всех перед законом ${ }^{15}$. В данном смысле протестные движения, акции неповиновения суть проявления гражданской, а не политической активности. Наиболее ярким подтверждением тому стало движение «За честные выборы», последовавшее за парламентскими выборами декабря 2011 г. Подобная трактовка гражданского участия, на наш взгляд, в полной мере учитывает особенности российского социально-политического контекста. Проблема гражданского участия возникает там, где существуют политические ограничения для выражения мнения и объединения рядовых граждан. Так что движение «За честные выборы» имело прямое отношение к проблеме защиты демократических принципов, поскольку речь шла об ущемлении гражданских прав, гарантированных законом. В аргументации М. Олсона, демократия не может считаться жизнеспособной, если принцип верховенства закона не применяется, когда дело касается смены действующей администрации по окончании срока ее полномочий. Демократия не может выжить и в том случае, если противники действующей администрации не могут пользоваться свободой слова и полнотой прав в соответствии с верховенством права ${ }^{16}$.

Таким образом, различение гражданского и политического участия акцентирует внимание, прежде всего, на степени включенности (исключенности) в институциональные отношения, но имеет также другие параметры сравнения. Одним из таких параметров является соотношение аксиологической и парксеологической рефлексии гражданских и социальных прав. По мнению ряда авторов, гражданская активность в отличие от социальной активности не включает в себя конкретные социальные проблемы и требования отдельных социальных групп, не представляет и не идентифицирует себя с данной социальной группой ${ }^{17}$. Тем не менее, нет никаких сомнений, что без осознания гражданских прав невозможна реализация прав социальных. Социальная активность и гражданская активность часто сопровождается перемещением акцента с социальных проблем на гражданские, т.е. реализации своего права влиять на политику, определяющую общественные условия их жизни, что еще раз подтверждает высокую степень политизации российского общества и публичной жизни. В отличие от дискурса развитых демократий, где гражданское участие является синонимом социального участия и определяется как организованная добровольная деятельность, направленная на решение проблем и помощь другим ${ }^{18}$.

Различение гражданского и политического важно не только как методологическая, но и как нормативная перспектива. Модели демократии обязательно включают подвижный баланс между описательно-объяснительными и нормативными утверждениями; то есть между утверждениями о том, как и почему дела обстоят именно так, и утверждениями о том, как должны обстоять дела. Гражданская активность, рост потенциала гражданского общества рассматриваются при этом как необходимые условия развития политического пространства, становления современных политических институтов. Отсутствие же дифференциации политического и гражданского говорит не только о слабости гражданского общества, но в целом о специфике сложившейся в нашей стране социально-политической системы.

Речь идет, прежде всего, о высокой степени централизации и политизации всех сфер общественной жизни. Ярким примером тому являются «прямые линии с Владимиром Путиным», в рамках которых президент страны отвечает на вопросы россиян по «самым актуальным общественнополитическим вопросам». В одной из «прямых линий» президенту страны пришлось решать вопрос, в том числе, об обустройстве детской пло-

\footnotetext{
17 Городские движения России в 2009-2012 годах: на пути к политическому. М.: Новое литературное обозрение, 2013. C.521.

18 A New Engagement? Political Participation, Civic Life, and the Changing American Citizen / Ed. by C. Zukin, S. Ceeter et al. Oxford: Oxford University Press, 2006. P.9-10.
} 


\section{Политика и общество 9 (117) • 2014}

щадки в поселке Новошахтинский ${ }^{19}$. Данный пример наглядно показывает, что любой маломальский вопрос в нашей стране может стать политическим, если речь идет об обращении к высшему должностному лицу государства. Достаточно распространенная практика соединять решение конкретной социальной проблемы и критику отдельных чиновников и органов власти и управления, на наш взгляд, является своеобразной формой, содержащей в себе одновременно признаки политической, гражданской и социальной активности. Политической - потому что данная деятельность реализуется в рамках подготовленных, отобранных и согласованных мероприятий властных структур. Гражданской - потому что инициатор вопроса затрагивает проблему отстаивания гражданских прав в отношениях с органами власти. Наконец, социальной - потому что вопрос касается решения конкретной социальной проблемы. В целом, речь идет о политической составляющей решения практически всех социальных проблем в нашей стране, когда смысловая начинка любого акта коммуникации власти и общества предполагает не только способ решения собственно проблемы, но также способ утверждения высшей, центральной власти.

Таким образом, переплетение политических, гражданских и социальных интересов, как и функциональных пространств для их обсуждения и реализации, является, пожалуй, главной особенностью активистской деятельности в нашей стране. В известном смысле огосударствление публичной сферы «сплачивает» общество, но тормозит процесс возникновения и развития социальных новаций. Между тем, деятельность разнообразных самоорганизованных, самостоятельных групп граждан, которые совершают активные действия в публичном пространстве, направленные на решение конкретных проблем и/или самореализацию человека как творца качества своей жизни и перемен в жизни важного для него сообщества, является интегральной особенностью современных сложных обществ. Плюрализация общественных отношений пред-

\footnotetext{
${ }^{19}$ См.: Специальная программа «Прямая линия с Владимиром Путиным». 25 апреля 2013 г. Стенограмма. Сайт программы. Доступ: http://www.moskva-putinu.ru/ (проверено 20.03 2014).
}

полагает существование различных типов социальной активности. С этой точки зрения, рост гражданского неполитического активизма может рассматриваться не как реакция на публичную жизнь, но как увеличение типов участия, в которые граждане имеют возможность быть вовлечены, а, следовательно, внести свой вклад в развитие общества.

Гражданский неполитический активизм и общественное развитие. Сам факт выхода за рамки формальных институтов, казалось бы, говорит о снижении уровня доверия в обществе публичным институтам и росте социального доверия, необходимого для коллективных действий. Однако уровень социального доверия в отдельно взятой стране мало репрезентативен сам по себе и может быть адекватно интерпретирован только с учетом текущего социально-политического контекста, а также в сравнении с уровнем институционального доверия и в межстрановом сопоставлении. Как показывают результаты исследований, уровень доверия публичным институтам зависит, как от уровня благополучия и удовлетворенности условиями жизни, включая стабильность общественно-политической ситуации, так и от уровня гражданской активности и наличия возможностей открыто выражать свои взгляды. Согласно данным Организации экономического сотрудничества и развития (ОЭСР) за 2013 г., в РФ политическим институтам доверяют 44\% граждан, что меньше, чем в среднем по странам ОЭСР - 56\%. При этом наибольшие значения отмечены в тех странах, в которых гарантия гражданских прав сочетается с высоким уровнем жизни и политической стабильностью. Показательно, что уровень институционального доверия коррелирует с уровнем социального доверия (см. рис.1). Сравнение данных ОЭСР и результатов исследования «Связь между социальным доверием и человеческими ценностями в Европе» показали, что радиус социального доверия выше в тех странах, где уровень институционального доверия также выше $\mathrm{e}^{20}$.

\footnotetext{
${ }^{20}$ Cм.: OECD Better Life Index // http://oecdbetterlifeindex.org/; Жители благополучных стран чаще доверяют незнакомцам. Презентация исследования Н. Михальски «Связь между социальным доверием и человеческими ценностями в Европе» // http://opec.ru/1617411.html (дата просмотра 20.03.2014 г .)
} 


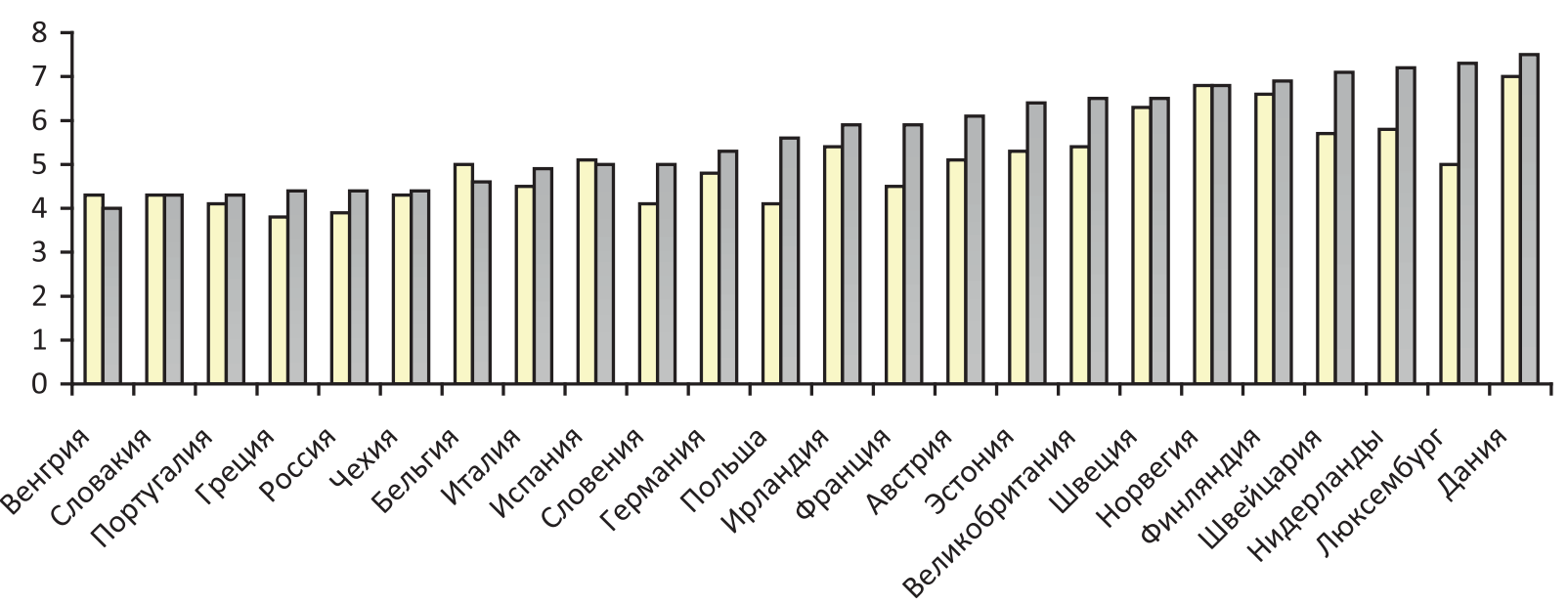

$\square$ Социальное доверие $\square$ Институциональное доверие

Источник: http://oecdbetterlifeindex.org/; http://opec.ru/1617411.html

Рисунок 1

Соотношение уровней институцчионального и соцчиального доверия, по 10-балльной шкале

Как показывают приведенные данные, в отдельных странах имеет место существенное различие в соотношении уровней институционального и социального доверия. Так, в скандинавских странах уровень социального и институционального доверия практически одинаков. Уместно предположить, что недоверие государственным институтам должно компенсироваться высоким уровнем доверия социального, готовностью людей к коллективным действиям, самоорганизации и самоуправлению. Однако, как показывают исследования, социальное доверие, основанное на преобладании индивидуальных, групповых, а не общегражданских интересов, ведет к архаизации общественных отношений ${ }^{21}$. В данном смысле, рост неполитической гражданской активности в случае перерастания ее в протестные действия может представлять угрозу стабильности существующего социально-политического порядка. Наглядным примером тому стали события на Украине в конце 2013 - начале 2014 гг,, когда движение в защиту гражданских прав сменилось антиправительственными выступлениями, приведшим, в конечном счете, к свержению законно избранной власти.

${ }^{21}$ Бызов Л.Г. Контуры новорусской трансформации. Социокультурные аспекты формирования современной российской нации и эволюция социально-политической системы. М.: РОССПЭН, 2013. С.50.
Грань между конструктивными и деструктивными действиями определяется возможностями достижения консенсуса относительно перспектив общественного развития, чего, кстати, не было достигнуто в российском обществе ни в начале1990-х гг., проблематичен он и в настоящее время. Можно предположить, что социально-экономический рост, улучшение благосостояния граждан, растущий социальный оптимизм на рубеже 2000-2010-х гг. объективно способствовали росту социального и институционального доверия. Тем более неожиданной и критически воспринятой в обществе стала рокировка во власти (2011-2012 гг.), фактически остановившая процесс модернизации российской политической системы. Последовавшее за этим протестное движение «За честные выборы» поставило под сомнение легитимность существующих политических институтов, что в свою очередь дало власти повод развернуть дискуссию о консервативной перспективе развития российского общества.

Примечательно, что и консервативная, и либеральная аргументация, но каждая со своей стороны, указывают на то, что излишняя политическая централизация, действительно, сдерживает темпы общественного развития. Консервативная аргументация связывает преодоление политической централизации и модернизацию политических институтов не с ростом уровня их демократичности, 


\section{Политика и общество 9 (117) • 2014}

a c повышением их устойчивости и организованности, внутренней сплоченности и автономии, которые гарантируют адаптацию к постоянно меняющимся условиям и обстоятельствам социальной жизни ${ }^{22}$. В рамках консервативной традиции главным источником модернизации является как раз конфликт между обществом и институтами, социальной мобилизацией и институционализацией, между включенными и исключенными из политической системы интересами. Представители либерального направления в качестве основного критерия политической модернизации, напротив, выделяют степень открытости политической системы для включения новых социальных групп, взглядов и интересов ${ }^{23}$. Таким образом, различие консервативного и либерального варианта политической модернизации лишь подчеркивает противоречивую связь между политической, гражданской и социальной составляющей активистской деятельности.

Противоречивая взаимосвязь трансформации политического и социального стала одной из главных тем теории рефлексивной модернизации У. Бека и Э. Гидденса, которые не противопоставляют политику и общество, но, напротив, выделяют общество как область суб-политики, и это не столько уровень, сколько указание направления - политика снизу ${ }^{24}$. Суб-политика воплощает подвижность и разнообразие, амбивалентность и неопределенность жизни современного социума. Трансляция интересов общества в публичную политику требует не столько формальных процедур, сколько разнообразных каналов и технологий взаимодействия
- в отличие от управленческого и партийного истэблишмента, чья политическая монополия инкорпорирована в идеологию и право.

Отсутствие возможностей «публичного оспаривания» (термин Р. Даля) государственной политики (то, что многие институты работают не эффективно, признают сами чиновники) провоцирует рост протестного, оппозиционного активизма. В начале XXI в. протестные кампании и движения, нацеленные на государство, становятся обычной частью политической жизни. В этих условиях протестные движения и в широком смысле гражданский активизм по сути стали новой формой влияния общества на государство и его институты. Собственно, исторически именно коллективные социальные движения сделали государство более ответственными перед чаяниями обычных людей, они приводят в общественно-политическую жизнь новые группы, новые идеи, новые коалиции и новые интересы, так что даже сильные недемократические тенденции ослабевают.

Гражданский активизм является органичной частью жизни современного общества, и все многообразие концептуальных моделей гражданской активности, так или иначе, соотносится с существующими на конкретном этапе парадигмами социального развития. Именно смена парадигм задает поиск «новых» направлений и форм гражданской активности. «Новизна» в данном случае отражает целый комплекс изменений, происходящих в обществе, и проявление новых форм и направлений гражданской активности можно рассматривать как часть этого обновления.

\section{Библиография:}

1. Бызов Л.Г. Контуры новорусской трансформации. Социокультурные аспекты формирования современной российской нации и эволюция социально-политической системы. М.: РОССПЭН, 2013. - 390 с.

2. Городские движения России в 2009-2012 годах: на пути к политическому. М.: Новое литературное обозрение, 2013. - 544 с.

3. Гражданское и политическое в российских общественных практиках. М.: РОССПЭН, 2013. - 525 с.

4. Даль Р.А. Полиархия: участие и оппозиция / пер. с англ. М.: Изд. дом ГУ-ВШЭ, 2010. -288 с.

5. Локк Дж. Два трактата о правлении. М.: Социум, 2014. - 308 с.

6. Олсон М. Власть и процветание: Перерастая коммунистические и капиталистические диктатуры. М.: Новое издательство, 2012. - 165 с.

\footnotetext{
${ }^{22}$ Huntington S.P. Political Order in Changing Societies. New Haven, London: Yale University Press, 1996. P.12.

${ }_{23}^{23}$ Даль Р.А. Полиархия: участие и оппозиция / пер. с англ. М.: Изд. дом ГУ-ВШЭ, 2010. С.30.

${ }^{24}$ Beck $U$. Die Erfindung des Politischen. Zu einer Theorie reflexiver Modernisierung. F/M: Suhrkampf, 1993. S.154-163.
} 
7. Павлова Т.В. Социальные движения как фактор трансформации институциональной среды: проблемы теории // Полис. 2008. № 5. С.113-124.

8. Петухов В.В. Гражданская активность как альтернатива антидемократическому тренду российской политики // Полис. 2013. № 5. С.87-99.

9. Психология политического восприятия в современной России / под ред. Е.Б. Шестопал. М.: РОССПЭН, 2012. 423 c.

10. Российский неполитический активизм. Отчет о результатах исследования. Пермь: ПК «Астер», $2014 .-158$ с.

11. Россия на новом переломе: страхи и тревоги / под ред. М.К. Горшкова, Р. Крумма, В.В. Петухова. М.: Альфа-М, 2009. - 160 с.

12. Х Хелд Д. Модели демократии. М.: Издательский дом «Дело» РАНХиГС, 2014. - 544 с.

13. Яницкий О.Н. Социальные движения: теория, практика, перспектива. М.: Новый хронограф, 2013. - 360 .

14. A New Engagement? Political Participation, Civic Life, and the Changing American Citizen / Ed. by C. Zukin, S. Ceeter et al. Oxford: Oxford University Press, 2006. - 272 p.

15. Beck U. Die Erfindung des Politischen. Zu einer Theorie reflexiver Modernisierung. F/M: Suhrkampf, 1993. - 302 p.

16. Huntington S.P. Political Order in Changing Societies. New Haven, London: Yale University Press, 1996. - 488 p.

17. Melucci A. Challenging Codes: Collective Action in the Information Age. Cambridge: Cambridge University Press, 1996. $-441 \mathrm{p}$.

18. Tarrow S.G. Power in Movement: Social Movements and Contentious Politics. Cambridge: Cambridge University Press, 2011. -328 p.

19. Touraine A. Social transformations of the twentieth century // International Social Science Journal. 1998. № 156. P.165-171.

20. Touraine A. What Is Democracy? Oxford: Westview Press, 2008. - 256 p.

21. Verba S., Norman H., Nie J. Participation and Political Equality: A Seven-Nation Comparison. Cambridge: Cambridge University Press, 1978. $-420 \mathrm{p}$

22. Хорина Г.П. Демократия в современной российской культуре: идеал и реальность // NB: Культуры и искусства. 2013. - 4. - C. 1-15. DOI: 10.7256/2306-1618.2013.4.6973. URL: http://www.e-notabene.ru/ca/article 6973.html

23. Попов Е.А., Максимова С.Г. Современное гражданское общество в России: проблемы становления и регионального развития // NB: Проблемы общества и политики. - 2012. - 1. - C. 1-20. URL: http://www.e-notabene.ru/pr/ article_38.html

24. Зайцев А.В. Институциональный диалог в сфере коммуникации государства и гражданского общества: теоретико-методологический подход // NB: Проблемы общества и политики. - 2012. - 1. - С. 21-54. DOI: 10.7256/23060158.2012.1.110. URL: http://www.e-notabene.ru/pr/article_110.html

25. Зайцев А.В. Философия диалога и диалогика гражданского общества: истоки и сущность // NB: Философские исследования. - 2012. - 4. - C. 1-53. DOI: 10.7256/2306-0174.2012.4.143. URL: http://www.e-notabene.ru/fr/ article_143.html

26. Зайцев А.В. Новая Агора: гражданский диалог в Евросоюзе // NB: Вопросы права и политики. - 2012. - 2. - С. 6289. DOI: 10.7256/2305-9699.2012.2.123. URL: http://www.e-notabene.ru//r/article_123.html

27. Боярских А. В. Краевые политические партии и региональные общественные движения в контексте гражданского общества Тюменского края//Национальная безопасность / nota bene, №2-20

28. Зайцев А.В. Диалогика Юргена Хабермаса: понятие и сущность // NB: Философские исследования. - 2012. - 2. - С. 75-98. DOI: 10.7256/2306-0174.2012.2.148. URL: http://www.e-notabene.ru/fr/article_148.html

29. Зайцев А.В. Гражданский диалог в ЕС и Евразийский интеграционный проект: сравнительно-дискурсивный анализ // NB: Международные отношения. - 2012. - 1. - С. 130-148. DOI: 10.7256/2306-4226.2012.1.130. URL: http:// www.e-notabene.ru/wi/article_130.htm

30. Алейников А.В. Системные конфликты в России: концептуальные основания анализа. Статья II. // NB: Проблемы общества и политики. - 2013. - 8. - C. 1 - 47. DOI: 10.7256/2306-0158.2013.8.5109. URL: http://www.e-notabene.ru/ pr/article_5109.html

31. Алейников А.В. Системные конфликты в России: концептуальные основания анализа. Статья 1. // NB: Проблемы общества и политики. - 2013. - 7. - C. 94 - 140. DOI: 10.7256/2306-0158.2013.7.2306. URL: http://www.e-notabene. $\mathrm{ru} / \mathrm{pr} / \mathrm{article \_ 2306.html}$

32. Тимшина Е.Л. Женские неправительственные объединения в современной России: новые методы исследования // NB: Вопросы права и политики. - 2013. - 4. - C. 89 - 109. DOI: 10.7256/2305-9699.2013.4.675. URL: http://www.enotabene.ru/lr/article_675.html

33. Щупленков О.В., Щупленков Н.О. Конституционные основы информационной свободы в России // NB: Вопросы права и политики. - 2013. - 10. - С. 35 - 92. DOI: 10.7256/2305-9699.2013.10.9617. URL: http://www.e-notabene.ru/ lr/article $9617 . \mathrm{html}$

34. Хорина Г.П. Демократия в современной российской культуре: идеал и реальность // NB: Культуры и искусства. 2013. - 4. - C. 1 - 15. DOI: 10.7256/2306-1618.2013.4.6973. URL: http://www.e-notabene.ru/ca/article_6973.html 


\section{Политика и общество $9(117) \cdot 2014$}

35. Щупленков О.В., Щупленков Н.О. Новый либерализм - исторические предпосылки и современные тенденции в России // NB: Проблемы общества и политики. - 2013. - 10. - C. 74 - 125. DOI: 10.7256/2306-0158.2013.10.9279. URL: http://www.e-notabene.ru/pr/article 9279.html

36. Попов Е.А., Максимова С.Г. Современное гражданское общество в России: проблемы становления и регионального развития // NB: Проблемы общества и политики. - 2012. - 1. - C. 1 - 20. URL: http://www.e-notabene.ru/pr/ article_38.html

37. Кабанов П.А. Политическая преступность в России: криминологический анализ исторического развития // NB: Вопросы права и политики. - 2013. - 1. - С. 285 - 304. DOI: 10.7256/2305-9699.2013.1.474. URL: http://www.enotabene.ru/lr/article_474.html

38. Борисенков А.А. О критериях политической деятельности // NB: Вопросы права и политики. - 2013. - 4. - C. 373 397. DOI: 10.7256/2305-9699.2013.4.652. URL: http://www.e-notabene.ru/lr/article_652.html

\section{References (transliterated):}

1. Byzov L.G. Kontury novorusskoi transformatsii. Sotsiokul'turnye aspekty formirovaniya sovremennoi rossiiskoi natsii i evolyutsiya sotsial'no-politicheskoi sistemy. M.: ROSSPEN, 2013. - $390 \mathrm{~s}$.

2. Dal' R.A. Poliarkhiya: uchastie i oppozitsiya / per. s angl. M.: Izd. dom GU-VShE, 2010. - $288 \mathrm{~s}$.

3. Lokk Dzh. Dva traktata o pravlenii. M.: Sotsium, 2014. - 308 s.

4. Olson M. Vlast' i protsvetanie: Pererastaya kommunisticheskie i kapitalisticheskie diktatury. M.: Novoe izdatel'stvo, 2012. $-165 \mathrm{~s}$.

5. Pavlova T.V. Sotsial'nye dvizheniya kak faktor transformatsii institutsional’noi sredy: problemy teorii // Polis. 2008 . № 5. S.113-124.

6. Petukhov V.V. Grazhdanskaya aktivnost' kak al'ternativa antidemokraticheskomu trendu rossiiskoi politiki // Polis. 2013. № 5. S.87-99.

7. Kheld D. Modeli demokratii. M.: Izdatel'skii dom «Delo» RANKhiGS, 2014. - $544 \mathrm{~s}$.

8. Yanitskii O.N. Sotsial'nye dvizheniya: teoriya, praktika, perspektiva. M.: Novyi khronograf, 2013. - 360 .

9. Beck U. Die Erfindung des Politischen. Zu einer Theorie reflexiver Modernisierung. F/M: Suhrkampf, 1993. - 302 p.

10. Huntington S.P. Political Order in Changing Societies. New Haven, London: Yale University Press, $1996 .-488$ p.

11. Melucci A. Challenging Codes: Collective Action in the Information Age. Cambridge: Cambridge University Press, 1996. $-441 \mathrm{p}$.

12. Tarrow S.G. Power in Movement: Social Movements and Contentious Politics. Cambridge: Cambridge University Press, 2011. -328 p.

13. Touraine A. Social transformations of the twentieth century // International Social Science Journal. 1998. № 156. P.165171.

14. Touraine A. What Is Democracy? Oxford: Westview Press, 2008. - 256 p.

15. Verba S., Norman H., Nie J. Participation and Political Equality: A Seven-Nation Comparison. Cambridge: Cambridge University Press, 1978. $-420 \mathrm{p}$

16. Khorina G.P. Demokratiya v sovremennoi rossiiskoi kul'ture: ideal i real'nost' // NB: Kul'tury i iskusstva. - $2013 .-4$. - C. 1-15. DOI: 10.7256/2306-1618.2013.4.6973. URL: http://www.e-notabene.ru/ca/article_6973.html

17. Popov E.A., Maksimova S.G. Sovremennoe grazhdanskoe obshchestvo v Rossii: problemy stanovleniya i regional'nogo razvitiya // NB: Problemy obshchestva i politiki. - 2012. - 1. - C. 1-20. URL: http://www.e-notabene.ru/pr/article_38.html

18. Zaitsev A.V. Institutsional' 'nyi dialog v sfere kommunikatsii gosudarstva i grazhdanskogo obshchestva: teoretikometodologicheskii podkhod // NB: Problemy obshchestva i politiki. - 2012. - 1. - C. 21-54. DOI: 10.7256/23060158.2012.1.110. URL: http://www.e-notabene.ru/pr/article_110.html

19. Zaitsev A.V. Filosofiya dialoga i dialogika grazhdanskogo obshchestva: istoki i sushchnost', // NB: Filosofskie issledovaniya. - 2012. - 4. - C. 1-53. DOI: 10.7256/2306-0174.2012.4.143. URL: http://www.e-notabene.ru/fr/article_143.html

20. Zaitsev A.V. Novaya Agora: grazhdanskii dialog v Evrosoyuze // NB: Voprosy prava i politiki. - 2012. - 2. - C. 62-89. DOI: 10.7256/2305-9699.2012.2.123. URL: http://www.e-notabene.ru/lr/article_123.html

21. Boyarskikh A. V. Kraevye politicheskie partii i regional'nye obshchestvennye dvizheniya v kontekste grazhdanskogo obshchestva Tyumenskogo kraya//Natsional'naya bezopasnost' / nota bene, №2-20

22. Zaitsev A.V. Dialogika Yurgena Khabermasa: ponyatie i sushchnost', // NB: Filosofskie issledovaniya. - 2012. - 2. - C. 75-98. DOI: 10.7256/2306-0174.2012.2.148. URL: http://www.e-notabene.ru/fr/article_148.html

23. Zaitsev A.V. Grazhdanskii dialog v ES i Evraziiskii integratsionnyi proekt : sravnitel'no-diskursivnyi analiz // NB: Mezhdunarodnye otnosheniya. - 2012. - 1. - C. 130-148. DOI: 10.7256/2306-4226.2012.1.130. URL: http://www.e-notabene. ru/wi/article_130.htm 
24. Aleinikov A.V. Sistemnye konflikty v Rossii: kontseptual'nye osnovaniya analiza. Stat'ya II. // NB: Problemy obshchestva i politiki. - 2013. - 8. - C. 1 - 47. DOI: 10.7256/2306-0158.2013.8.5109. URL: http://www.e-notabene.ru/pr/article_5109. html

25. Aleinikov A.V. Sistemnye konflikty v Rossii: kontseptual'nye osnovaniya analiza. Stat'ya 1. // NB: Problemy obshchestva i politiki. - 2013. - 7. - C. 94 - 140. DOI: 10.7256/2306-0158.2013.7.2306. URL: http://www.e-notabene.ru/pr/article 2306.html

26. Timshina E.L. Zhenskie nepravitel'stvennye ob' 'edineniya v sovremennoi Rossii: novye metody issledovaniya // NB: Voprosy prava i politiki. - 2013. - 4. - C. 89 - 109. DOI: 10.7256/2305-9699.2013.4.675. URL: http://www.e-notabene.ru/ 1r/article_675.html

27. Shchuplenkov O.V., Shchuplenkov N.O. Konstitutsionnye osnovy informatsionnoi svobody v Rossii // NB: Voprosy prava i politiki. - 2013. - 10. - C. 35 - 92. DOI: 10.7256/2305-9699.2013.10.9617. URL: http://www.e-notabene.ru/lr/article_9617.html

28. Khorina G.P. Demokratiya v sovremennoi rossiiskoi kul'ture: ideal i real'nost' // NB: Kul'tury i iskusstva. - 2013. - 4. - C. 1 - 15. DOI: 10.7256/2306-1618.2013.4.6973. URL: http://www.e-notabene.ru/ca/article_6973.html

29. Shchuplenkov O.V., Shchuplenkov N.O. Novyi liberalizm - istoricheskie predposylki i sovremennye tendentsii v Rossii // NB: Problemy obshchestva i politiki. - 2013. - 10. - C. 74 - 125. DOI: 10.7256/2306-0158.2013.10.9279. URL: http:// www.e-notabene.ru/pr/article_9279.html

30. Popov E.A., Maksimova S.G. Sovremennoe grazhdanskoe obshchestvo v Rossii: problemy stanovleniya i regional'nogo razvitiya // NB: Problemy obshchestva i politiki. - 2012. - 1. - C. 1 - 20. URL: http://www.e-notabene.ru/pr/article_38. html

31. Kabanov P.A. Politicheskaya prestupnost' v Rossii: kriminologicheskii analiz istoricheskogo razvitiya // NB: Voprosy prava i politiki. - 2013. - 1. - C. 285 - 304. DOI: 10.7256/2305-9699.2013.1.474. URL: http://www.e-notabene.ru/lr/article 474.html

32. Borisenkov A.A. O kriteriyakh politicheskoi deyatel'nosti // NB: Voprosy prava i politiki. - 2013. - 4. - C. 373 - 397. DOI: 10.7256/2305-9699.2013.4.652. URL: http://www.e-notabene.ru/lr/article_652.html 